\title{
Insights into tectonic reactivation and landscape development processes at the Paraná Basin border using integrated geomorphometric and radiometric analyses
}

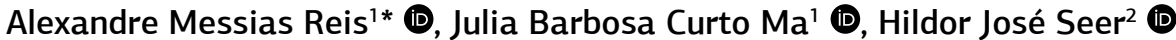

\begin{abstract}
In the Bom Jardim de Goiás region, the Transbrasiliano Lineament shows evidence of a fault reactivation along NE-SW structures (main direction) and secondary directions related to subsequent events. To study the structural framework and reactivation inputs toward tectonic events, distinctive features of the northern Paraná Basin border were analyzed by integrating gamma spectrometry and radar data, both supported by field research. The remote sensing database obtained by the Advanced Land Observing Satellite (ALOS) Phased Array type L-band Synthetic Aperture Radar (PALSAR) sensor allowed detecting lineaments and morphometric derivatives. Besides, the developed morphogenetic process images attest to the importance of structural control on relief evolution while concentrating lineaments as a function of lithological and geomorphological domains. Airborne gamma-ray spectrometry data processing focused on $\mathrm{K}_{\mathrm{d}}$ (Anomalous Potassium) and F-Parameter indices. In this context, the fuzzy logic and Index Overlay Method allowed multivalued integration that indicated hydrothermal products and weathering processes correlated with $\mathrm{K}_{\mathrm{d}}$ and F-Parameter anomalies. Thus, the joint interpretation of lineaments, geomorphological domains, and $\mathrm{K}_{\mathrm{d}} / \mathrm{F}$-Parameter anomalies allowed differentiating primary geological elements and products from surface dynamics, directly or indirectly related to tectonic reactivation processes.
\end{abstract}

KEYWORDS: ALOS PALSAR; gamma-ray spectrometry; anomalous potassium; F-parameter; fuzzy logic; index overlay method; tectonic reactivation; lineaments.

\section{INTRODUCTION}

Unique structural and tectonic features have been identified in the northern region of the Paraná Basin, Brazil, by previous geophysical studies and other regional surveys (Soares et al. 1982, Seer 1985, Machado and Souza 1990, Zalán et al. 1991, Marques et al. 1993, Milani et al. 2007, Pinheiro et al. 2019). These features are characterized by the impressive magnetic signature of the Transbrasiliano Lineament (TBL) (Vidotti et al. 2011, Curto et al. 2014, 2015, Pinto and Vidotti 2019), which limits major tectonic domains: Paraná Basin, Arenópolis Magmatic Arc (Brasília Belt), and Paraguay Belt (Cordani et al. 2010). The TBL reactivation from Ordovician to Cretaceous, mainly during the opening of the Atlantic (Alvarenga and Trompette 1993), and associated structures influenced the development of the Paraná Basin. In this context, the increasing availability of open remote sensing and high-resolution geophysical data represent the potential for applying methodologies for processing and integrating data to structural mapping in this area, which still lacks research studies on scales larger than 1:50.000.

${ }^{1}$ Universidade de Brasília - Brasília (DF), Brazil. E-mail: alex.messias. reis@gmail.com, julia.curto@gmail.com

${ }^{2}$ Centro Federal de Educação Tecnológica de Minas Gerais - Araxá (MG), Brazil. E-mail: hildorster@gmail.com

${ }^{*}$ Corresponding author.

(c) 2020 The authors. This is an open access article distributed under the terms of the Creative Commons license.
The quantitative and qualitative analyses of the dataset collected at different scales (from the synthetic scale of remotely sensed data to field outcrop surveys) in a Geographic Information System (GIS) environment allowed establishing relationships among radiometric signatures, morphogenetic compartments, and field features of the study area. Characterizing geomorphometric features (Pike et al. 2009) provides a better understanding of tectonic events from Paleozoic-Mesozoic to Pleistocene in the geological evolution of the northern Paraná Basin, besides correlating the surface dynamics with landscape development.

The main objective of this paper is to improve the understanding of the geomorphometry and structural settings of the northern Paraná Basin border by integrating airborne gamma-ray spectrometry, geological, and remote sensing data. To this end, we used lineament analysis, F-Parameter, and Anomalous Potassium $\left(\mathrm{K}_{\mathrm{d}}\right)$ methods. The two integration techniques used were (i) the Index Overlay Method (IOM) to assign different weights to each input map according to their relevance in the analysis, and (ii) the fuzzy modeling approach to build reliable integrated data.

\section{GEOLOGICAL SETTING}

The study area - located at the border region of the states of Goiás and Mato Grosso, Brazil - includes part of the northern Paraná Basin and its basement, bounded by the Brasília and Paraguay Neoproterozoic belts. The area covers the basin 
edge, at the boundary between sedimentary and basement rocks (Fig. 1).

\section{Arenópolis Magmatic Arc}

The Arenópolis Magmatic Arc (AMA), extending for several thousand kilometers in the southern Goiás Magmatic Arc, is one of the most important components of the Neoproterozoic Brasília Belt in central Brazil (Pimentel et al. 2000b). In the study area, AMA, to the east of the Serra Negra Fault (Seer 1985), is the main surface expression of the TBL system. Metamorphism reflecting the final closure of the Goiás Ocean and the continental collision took place between 650-630 Ma (Cordani et al.2003). The AMA consists of orthogneiss units related to a (meta) volcanic-sedimentary sequence, suggesting a tectonic origin similar to modern volcanic arcs in a subduction zone environment (Pimentel and Fuck 1987, Pimentel and Fuck 1992a, Pimentel 2016).

The Bom Jardim de Goiás Group, one of the complete volcano-sedimentary calcium-alkaline sequences of the AMA, is represented by mafic to felsic volcanic rocks close to the Serra Negra Fault domain in the study area. Quartz veins with tourmaline in contact with volcanic rocks indicate hydrothermalism associated with a fault region.

\section{Paraguay Belt and Cuiabá Group}

The Neoproterozoic Paraguay Belt, a Pan-African-Brasiliano orogeny along the Amazônia southeastern border, is characterized by low-grade metamorphic sedimentary rocks subjected to polyphase deformation (Alvarenga and Trompette 1993, Alvarenga et al. 2007). The succession recognized in the study area lies on the west of the TBL, represented mainly by the Cuiabá Group. These rocks were deposited over a marginal basin installed in a passive limit SE of the Amazonian Craton during the Cryogenian and later deformed. The lithostratigraphic division of the Cuiabá Group into Campina de Pedras, Acorizal, and Coxipó formations, including meta-rhythmites, metaconglomerates, sandstones, pelites, and massive subordinate diamictite horizons, has been described by Tokashiki and Saes (2008).

The pelitic metasedimentary rocks of the Cuiabá Group, in contact with AMA lithotypes, present crenulation overprinting an old foliation, shear zones, and fractures. Drag folds associated with fault zones and gouge, as well as cataclasites, evidence recent tectonics. Normal faults placed part of the Cuiabá Group at a relatively higher structural level compared to the Furnas Formation, illustrating a compositional geomorphological control.

\section{Neoproterozoic post-tectonic granites}

The study area has four known granite bodies - Serra Negra, Macacos, Bom Jardim, and Serra Verde. The first intrudes the AMA, the second intrudes both the AMA and the Cuiabá Group, and the last ones intrude the Cuiabá Group. Regional granitic intrusions create large calcium-alkaline bodies with K-rich compounds, comprising predominantly isotropic biotite and equigranular granites (Pimentel et al. 1999, Pimentel et al. 2000b).

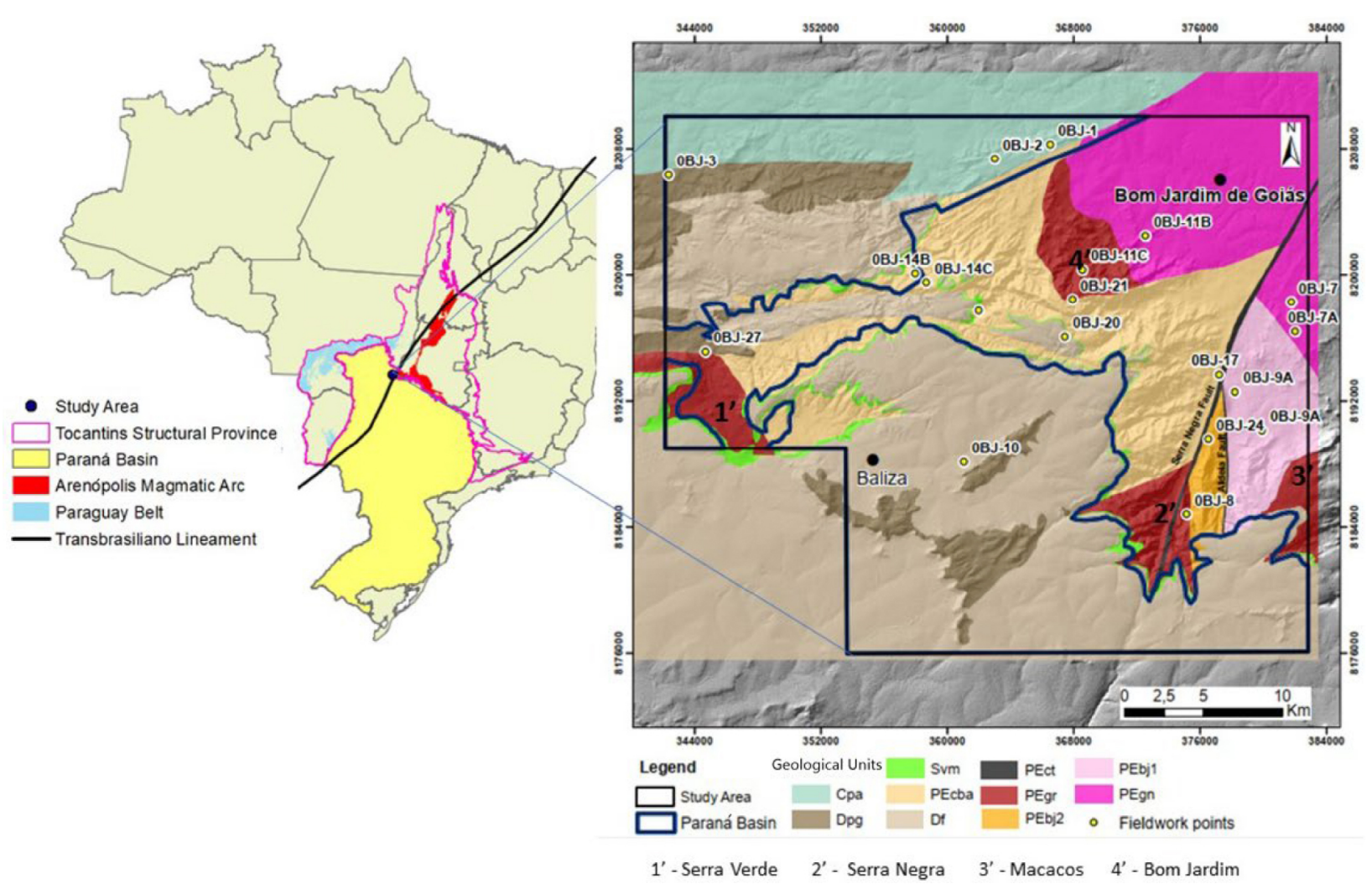

Figure 1. Geological map of the study area, adapted from Andrade et al. (2012). The basement of the Paraná Basin consists of PEgn: Paleoproterozoic Gneiss-basement; PEbj1 and PEbj2: Goiás Magmatic Arc Neoproterozoic units; PEgr: post-orogenic granites; PEct: Serra Negra Fault Cataclasites; PEcba: Cuiabá Group. The geological setting of the Paraná Basin consists of: Svm: Vila Maria/Iapó Formation (420 ma); Df: Furnas Formation (405 ma); Dpg: Ponta Grossa Formation (360 ma); Cpa: Aquidauana Formation (290 ma). 
Pimentel et al. (2000b) suggested two episodes of post-tectonic granite magmatism in Arenópolis - from 590 to $560 \mathrm{Ma}$ and from 508 to $485 \mathrm{Ma}$ - and classified the younger Serra Negra and Iporá granites as Type-A granites.

The location of the granitic intrusions is part of large calcium-alkaline bodies rich in potassium. Pegmatite veins show centimetric K-feldspar crystals. High magmatic concentration of potassium influences the geological context, even in a background naturally rich in potassium.

\section{Transbrasiliano lineament}

Magmatic arc rocks are affected by the TBL fault system, with an average trend of $\mathrm{N} 45^{\circ} \mathrm{E}$. (Seer 1985). This strike-slip fault system (Schobbenhaus et al. 1975) relates to the final stage of the Pan-African-Brasiliano orogeny (Marini et al. 1984, Cordani et al. 2010). The TBL predominant kinematics is dextral (Pimentel and Fuck 1992b); however, Seer (1985) inferred sinistral kinematics for this zone based on indicators and relative displacement of Macacos Granite. Extensional faults trending $\mathrm{N} 60^{\circ}$ and $\mathrm{N} 70^{\circ} \mathrm{E}$ are superimposed on the older tectonic lineament in the Phanerozoic (Curto 2015).

\section{Paraná Basin}

This large intracratonic basin in South America developed entirely on the continental crust, filled with sedimentary and volcanic rocks from Silurian to Cretaceous. It covers more than $1,000,000 \mathrm{~km}^{2}$ of the Brazilian territory while reaching depths of $7000 \mathrm{~m}$ (Zalán et al. 1987, Milani et al. 2007). The stratigraphic record reflects the high basin latitude throughout much of the Palaeozoic, consisting of five major depositional sequences (Silurian, Devonian, Permo-Carboniferous, Triassic, Juro-Cretaceous). The first four depositional sequences are predominantly siliciclastic in nature, while the fifth contains one of the largest continental flood basalts on Earth: the Cretaceous Serra Geral tholeiitic magmatism (Zalán et al. 1991). The study site included parts of the following basin formations - Furnas, Aquidauana, Vila Maria, and Ponta Grossa.

\section{LOCAL STRUCTURAL SETTING, FLUID MOBILIZATION, AND REACTIVATION PROCESSES}

According to Cordani et al. (2010), the structural and tectonic regimes affecting the study area involve several tectonic reactivations on the South American Platform, including the Cretaceous (Waldensian) event (Almeida 1967).

In the study area, Seer (1985) defines two transcurrent structures in the TBL system - the Serra Negra and Aldeia faults. The first, predominantly N25E, cuts through Phanerozoic sedimentary rock domains and is characterized by discontinuous gravitational and brittle faults. Using integrated geophysical and fieldwork data, Curto et al. (2014) indicate that N45-60E and N25-30E trending structures are deep crustal components of the TBL, from surface to lower crust levels.

Brittle faults and joints affect the basement N40-60W and N40-70E trends. Such structures overprint pre-existing structures as a result of reactivations that occurred until the
Mesozoic Era (Seer 1985). This scenario is confirmed by the Carboniferous and Devonian sequences of the Paraná Basin (Curto 2015). The N75W to E-W azimuthal family is strongly developed on vertical outcrops, and the N10-15W joints have both vertical and sub-vertical dips filled with quartz. The joint filling is also directly related to reactivations in the Aldeia Fault zone, where reactivations are associated with metamorphic rock foliation in the N10W direction.

Hydrothermal fluids may have played a role in the reactivation processes (e.g., Seer 1985, Harcouet-Menou et al.2009, Curto et al. 2014, Eleraki et al. 2017, Taillefer et al. 2017), causing the enrichment or depletion of $\mathrm{eTh} / \mathrm{K} / \mathrm{eU}$-bearing minerals. In the NE-SW Meatiq Shear Zone regional system (Egypt), Eleraki et al. (2017) found that most hydrothermal alteration zones are present at the sheared tectonic contact between different lithological units. The authors concluded that increasing Th could be interpreted as evidence of alteration through fractures and faults, while increasing $\mathrm{K}$ is related to weathering products. Both eTh and $\mathrm{K}$ anomalous values are correlated with tectonic reactivation processes.

Fault zone intersections improve fracture connections and favor the formation of enhanced directions of fluid circulation (Lucianetti et al. 2017, Pischiutta et al. 2013). Also, Harcouet-Menou et al. (2009) show that permeable layers and magmatic intrusions play an important role in controlling fluid drainage. According to Taillefer et al. (2017), the distribution of actual hydrothermal activity in the fault scarp relief of the Eastern Pyrenees (France) suggests that footwall topography is an essential parameter, allowing recharge and hydrothermal fluid circulation path. The authors argue that fault-related topography is crucial to establishing fluid advection and controlling hydrothermal activity intensity.

\section{REACTIVATION EVENTS AND BASIN FORMATION}

At least three events are indicative of TBL reactivation in the Phanerozoic - the formation of the Jaibaras Basin (Oliveira 2001) in the Cambrian-Ordovician; the formation of the Água Bonita Graben in the Silurian-Devonian; and the activation of a series of extensional structures during the opening of the Atlantic Ocean in the Late Cretaceous. The first sediments of the Paraná Basin in the Ordovician were deposited along the NE-SW depocenters formed by TBL reactivated structures (Zalán et al. 1991, Curto et al. 2014). Besides, Moura (2017) pointed out reactivations along the TBL between 450 and $429 \mathrm{Ma}$.

In the Late Cretaceous, a new sedimentation cycle overlapped more than 50\% of the Paraná Basin area, forming the Bauru Basin, which exhibits a major elongated shape, trending depocenter in the north-central portion of the Paraná Basin, with NNW-SSE and N-S preferred directions (Batezelli 2006). In the study area, small elongated basins related to the Bauru Basin have settled along the TBL reactivated structures.

The Pantanal Basin - from the Quaternary (Pleistocene) - is a neotectonic reactivation product along the TBL while its elongated elliptical depocenter is controlled by fault activity (Assine 2004). 
The Araguaia Formation of the Bananal Basin (Middle Pleistocene) is also controlled by the TBL (Sousa 2017) so that the Araguaia River is embedded in the northern extension of the Serra Negra Fault.

In addition to the works mentioned above, Brito Neves and Fuck (2013) and Pinheiro et al. (2019) recorded other Phanerozoic activities in the Paraná and Parnaíba basins. However, the known facts about reactivations are still based on scarce local data, while several knowledge gaps regarding tectonic evolution need to be filled.

\section{METHODS: DATABASE AND PROCESSING}

The remote sensing database was obtained from the elevation data of the ALOS PALSAR sensor. It allowed extracting lineaments and morphometric derivatives, as well as outlining geomorphological units and morphogenetic processes. Additionally, gamma-ray spectrometry data provided $\mathrm{K}_{\mathrm{d}}$ and F-Parameter indices. For data integration, the IOM assigned different weights to each input map according to their relevance in the analysis. Later, the fuzzy modeling approach was used to build reliable integrated data.

\section{Data sources}

On January 24, 2006, ALOS was launched from the Tanegashima Space Center by the Japan Aerospace Exploration Agency (JAXA) carrying three instruments - the Panchromatic Remote-Sensing Instrument for Stereo Mapping (PRISM), the Advanced Visible and Near Infrared Radiometer type 2 (AVNIR-2), and the PALSAR. (JAXA, 2006). PALSAR data are used to produce a digital elevation model (DEM) with a $12.5 \mathrm{~m}$ spatial resolution. The pre-processed data was provided byJAXA.

The DEM generated using the ALOS PALSAR (JAXA, 2006) data was assessed based on geomorphometric and structural lineament analyses. Two methods were used for remote sensing processing. In the first, morphometric parameters were extracted and combined in a color composite RGB image, visually analyzed on-screen to identify geomorphological units and morphogenetic processes. In the second, the lineaments at the basin edge were extracted, followed by the statistical analysis of the identified lineaments. We used the software ENVI (L3HARRIS) 5.2 and ArcMap 10.3 (ESRI) for data processing.

The study area was included in the systematic airborne geophysical survey conducted by the Geological Survey of Brazil (Serviço Geológico do Brasil - CPRM) and the Government of the State of Goiás. The survey acquired magnetic and gamma-ray spectrometry data along the parallel $\mathrm{N}$-S flight lines spaced approximately $500 \mathrm{~m}$, with $100 \mathrm{~m}$ ground clearance, and E-W control lines spaced 5,000 m.

\section{Processing}

\section{Surface morphometric parameters}

The altitude, slope, and curvature data derived from the surface topography were extracted and, subsequently, combined in the RGB color composition as follows: altitude in the red channel, slope in the green channel, and curvature in the blue channel. A similar approach was previously used by Castro (2010) and Hermuche (2002) to identify geomorphological units. Our analysis was based on color and textures, identifying similar features by visual inspection and interpretation.

\section{Lineament analysis and directional statistics}

Lineaments are alignments of tonal variation on the observed images (Cianfarra and Salvini 2014). The shaded relief technique consists of a 3D terrain surface model that uses simulated sunlight position. This method enhances the texture of linear features so that refined lineaments can be selected based on images that simulate the sunlight position.

The low vertical exaggeration (less than two times) has the purpose of avoiding displacement between lineaments extracted from different lighting angles.

Shaded images were generated according to radar-like synthetic lighting conditions, perpendicular to the N40-60W and N40-70E directions. The methodology developed sought to highlight two main directions, obtaining as many lineaments as possible. According to Seer (1985), these directions mark the principal lineaments known in the study area. This multiple combination of lightning conditions and morphological contrast is useful in shaded images to suppress apparent false rotation (Cianfarra and Salvini 2014). The lineaments were individually extracted using the ArcMap 10.3 vector tool.

We always identified lineaments by negative breaks, that is, in less illuminated features of the shaded image, in order to avoid duplication. Afterward, lineaments provided directional statistics in a wind rose diagram. These data got buffered into $50 \mathrm{~m}$ range polygons to increase the extent of the analysis displaying how tectonics acted.

\section{Pre-processing of radiometric data}

Spurious data and inconsistent values related to acquisition errors were removed from the database. The correction consisted of comparing the overall mean of each isotope with the mean of each isotope channel. After correction, a constant value corresponding to the difference between the overall and database means was added to each channel (IAEA 2002). Negative values were removed, followed by an interpolation of the dataset using the minimum curvature algorithm to fill the gaps left by these negative values. The software used was Oasis Montaj 9.4 and ArcMap 10.2.

\section{Anomalous potassium and F-Parameter}

The $\mathrm{K}_{d}$ methodology was developed by Saunders et al. (1994) and later used by Pires (1995) to highlight $K_{d}$ accumulations related to the dynamics of source and depositional areas.

Considering thorium as a resistant accessory mineral, its assembly values can be used to predict standard potassium values for a given lithotype. This correlation (K-Th) is represented by a linear function, obtained from the corrected data whose values describe the ideal potassium equation (Ki) (Eq. 1). The difference between corrected and ideal potassium values (obtained from the linear function) is known as the $\mathrm{K}_{d}$ (Eq. 2).

To determine $\mathrm{K}_{\mathrm{d}}$, a regression analysis of individual geological or geomorphological units in the study area is recommended. 
This methodology adopted to emphasize local anomalies aimed to suppress the regional background that may interfere with the analyses. The heterogeneous geological context of the study area allows adjusting the linear coefficient due to its compositional similarity with average crustal values. The adjustments correspond to overall lithological means used by the IAEA (2003):

$K i=a+b . T h$

In which:

$\mathrm{a}=$ the linear coefficient;

$\mathrm{b}=$ the angular coefficient.

$K d=\frac{(K i-K s)}{K i}$

In which:

$\mathrm{K}_{\mathrm{d}}=$ the observed deviation of potassium;

$\mathrm{Ks}=$ the original value, measured in the survey;

$\mathrm{Ki}=$ the ideal value

The process flow below synthesizes the steps followed (Fig. 2):

The F-Parameter (Gnojek and Prichystal 1985, Barbuena et al. 2013, Pereira and Ferreira 2018) derives from the contribution of potassium and uranium/thorium ratio. This procedure allows identifying different geological scenarios since relatively higher values correspond to areas with chemically altered rocks, whereas relatively lower values indicate areas with weathering of K-bearing minerals. Equation 3 defines this relationship:
$F=K x \frac{e U}{e T h}$

Gamma-ray spectrometry and remote sensing data were used for qualitative and visual analyses (including spatial data overlap). The process applies the IOM and fuzzy logic mathematical analysis.

\section{Index Overlay Method}

IOM was used to integrate different data layers of interest. Each class has a different weight within the layers, depending on their relative importance to the context (Bonham-Carter 1994) (Fig. 3). For this reason, $K_{d}$ values were first separated

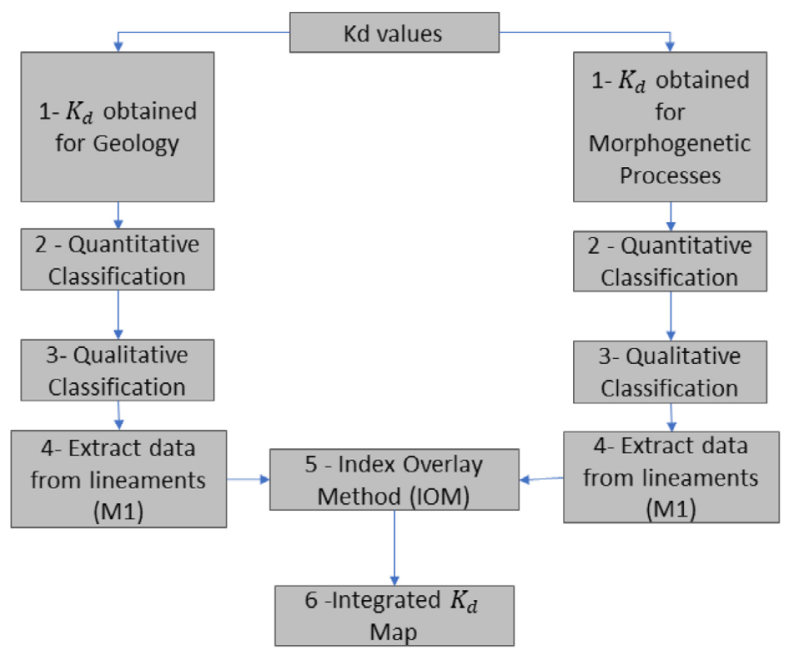

Figure 3. Process flowchart for data integration using the Index Overlay Method.

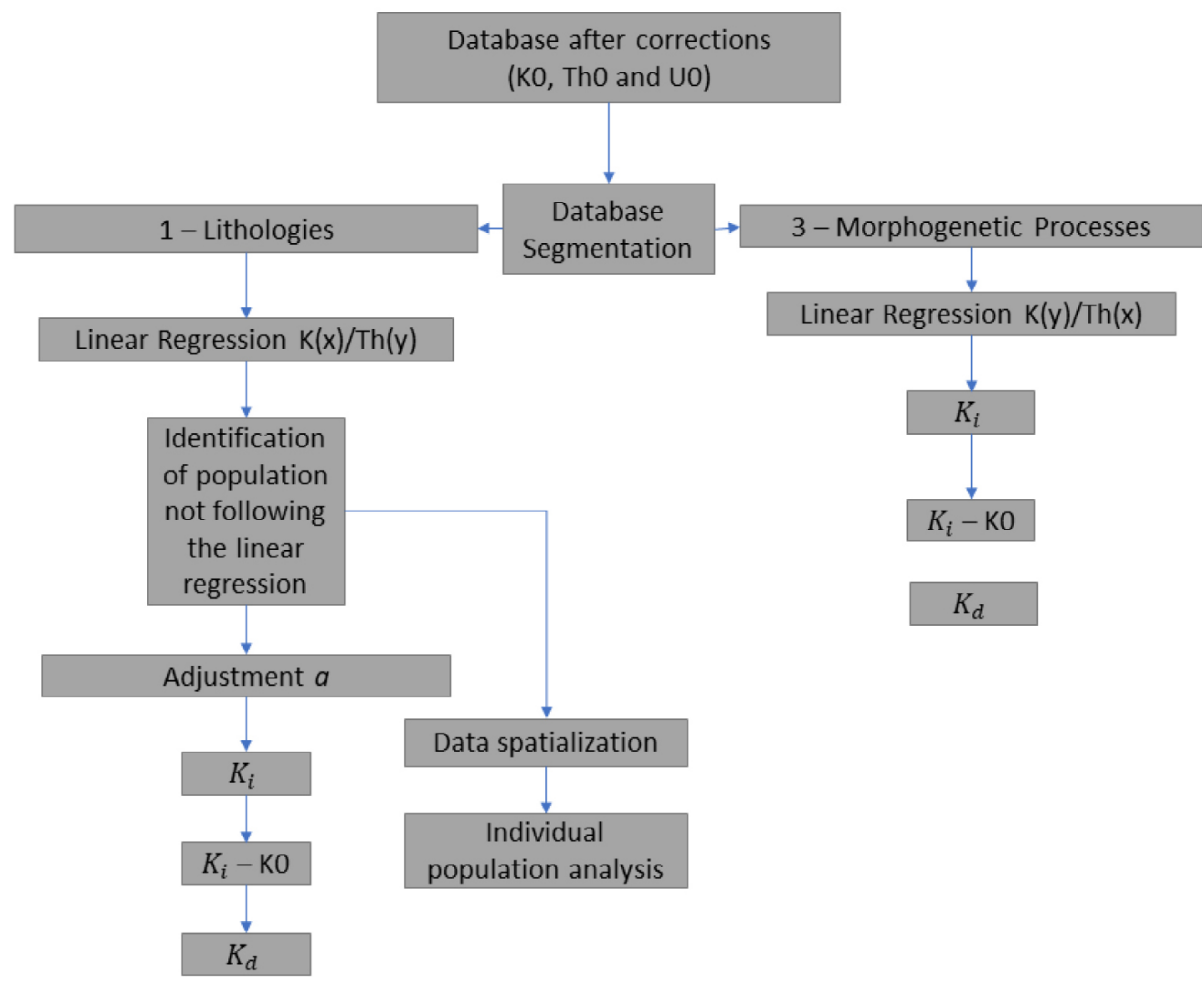

$\mathrm{K}_{\mathrm{i}}$ : ideal potassium; $\mathrm{K}_{\mathrm{d}}$ : anomalous potassium; a: linear coefficient.

Figure 2. Process flowchart for anomalous potassium $\left(\mathrm{K}_{\mathrm{d}}\right)$. 
into two layers - geological and morphogenetic processes. The following steps were taken for each layer:

- $\mathrm{K}_{\mathrm{d}}$ values were reclassified quantitatively so that all units were in the same range. This step is required because the basement has a heterogeneous composition;

- Jenks optimization method classified features by natural breaks in data values. The Jenks optimization method is also known as the goodness of variance fit (GVF) (ESRI 2019);

- After the quantitative classification, the values were ranked according to three qualitative classes (low, medium, and high $\mathrm{K}_{\mathrm{d}}$ );

Finally, the entire input was integrated by applying the IOM to all qualitative classes exclusively for $K_{d}$ values along the interpreted lineaments to understand the relationship between tectonics and radiometric composition.

\section{Fuzzy logic approach}

While standard logic applies only to completely true or completely false concepts, fuzzy logic generalizes standard logic, providing a degree of truth anywhere between 0.0 and 1.0 and allowing a gradual transition from false to true (Alamaniots et al. 2013). This value is chosen experimentally.

- After the $\mathrm{K}_{\mathrm{d}}$ values were separated according to geologi$\mathrm{cal}$ and morphogenetic process units, they were rescaled to $0-1$ values. Therefore, an MS Large function $\left(\mathrm{ESRI}^{\circledR}\right.$ ) was chosen to highlight the highest values. Next, a mosaic was made to gather the obtained data;

- A second rescale was required to standardize data in the software model. This step, called "fuzzification", is necessary to obtain the fuzzy membership. In the fuzzy membership processes, the MS Large function was used again;

- Subsequently, in the merging process, we used the "AND" operator, considering the highest coincident values in both data (from geological and morphogenetic processes) (Fig. 4).

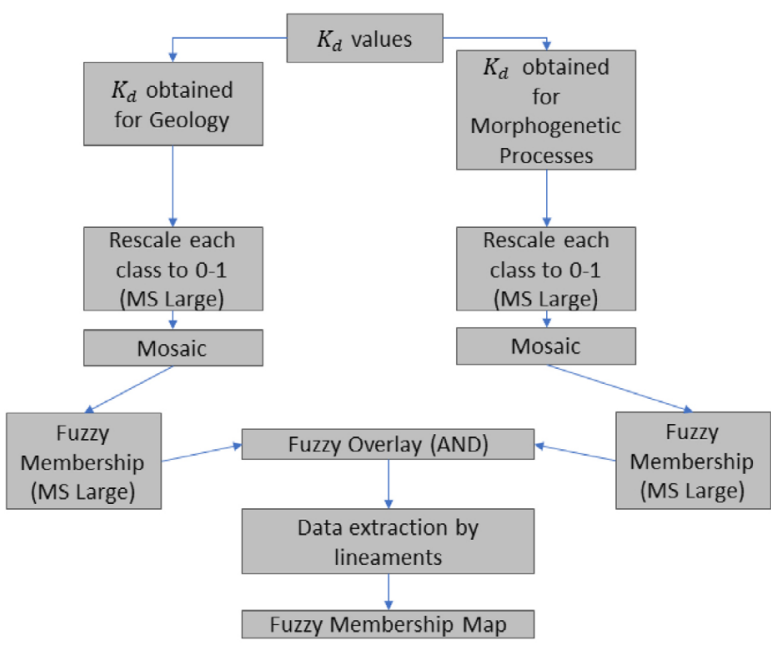

Figure 4. Process flowchart for data integration using the fuzzy logic approach.

\section{RESULTS}

\section{Geomorphometric and morphogenetic processes}

Geomorphometric and morphogenetic processes were analyzed according to economic zoning (MacroZEE 2014) to provide regional geomorphological information about Brazil. In the study area, geomorphological data are classified into Guimarães Plateau and Araguaia Surface units, corresponding to structural and homogeneous tabular dissections.

Geomorphometry, the science of quantitative land-surface analysis, is a modern, analytical-cartographic approach used to represent bare-earth topography by manipulating terrain height digitally (Pike et al. 2009). The RGB (R: altimetry, G: slope, and $\mathrm{B}$ : minimum curvature) ternary composition shows distinct zones that combine colors and textures (Fig. 5) ranked according to their importance and each morphometric parameter contribution to geomorphological units.

The classification followed the geomorphological units adopted by the Technical Manual for Geomorphology (IBGE 2009), a general guide commonly used in Brazil. Additionally, fieldwork data supported the ranking process and allowed identifying seven geomorphological units (Fig. 6), described as follow:

- Plateau units predominate in the area, corresponding to $448.78 \mathrm{~km}^{2}$ of the total. Altimetry is the most important morphometric parameter. The few existing morphodynamic processes support the formation of smooth relief with high elevation;

- Scarp retreat units are marked by a high slope compared to altimetry and curvature of the highest slopes in the area. Intense morphodynamic processes are responsible for sculpting the landscape. A well-demarcated limit between the most dynamically stable units highlights the boundaries where erosion and deposition of plateau sediments occur. Scarp retreat units cover an area of $212.51 \mathrm{~km}^{2}$;

- Colluvial slope units exhibit flat to smooth relief and slope softer than that of scarp retreat. However, the slope is high enough to carry the eroded materials to dissected plain units where drainage is plentiful;

- Dissected plain units are determined by the balance between slope and minimum curvature while accommodating sediments from plateau and scarp retreat units, covering approximately $129.49 \mathrm{~km}^{2}$. The relief is hilly, with no steep slopes, possibly indicating the presence of magmatic arc rocks. The flatland area is the second largest, corresponding to $327.97 \mathrm{~km}^{2}$;

- Residual hill units in the basin were identified in plateau units due to small features observed in the Paraná Basin - rocks originating from resistant sedimentary material and not affected by processes responsible for sculpting the landscape. They cover $48.71 \mathrm{~km}^{2}$ of the area, highlighting a few dynamic processes, such as local rock compositions hindering weathering;

- Residual hill units in the basement, on the other hand, are greatly weathered. They originate from acid igneous rocks and cover $44.07 \mathrm{~km}^{2}$ of the area; 

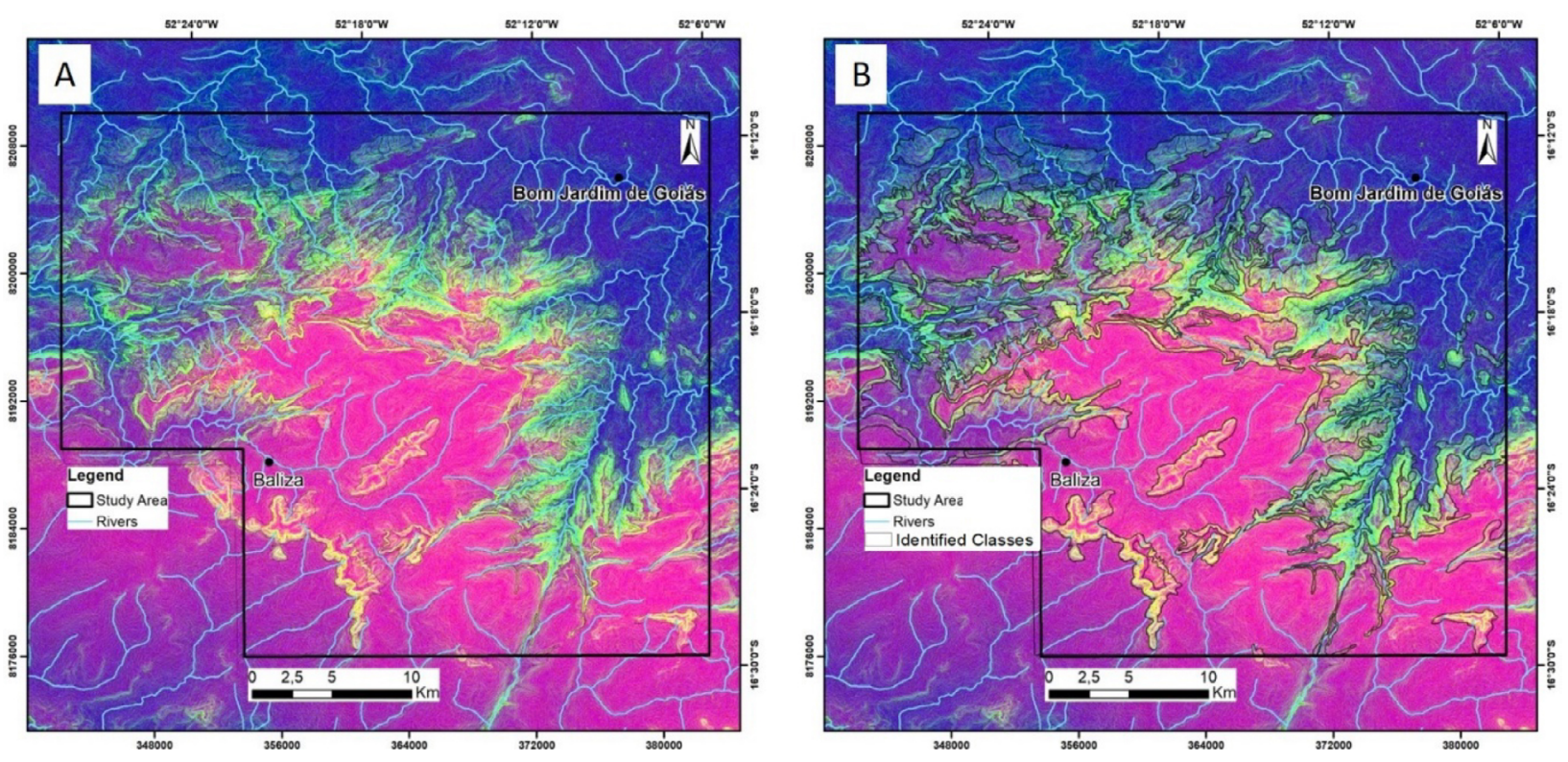

R: altimetry; G: slope; B: minimum curvature.

Figure 5. RGB color composition using relief morphometric parameters (A) and separation of geomorphological units (B).
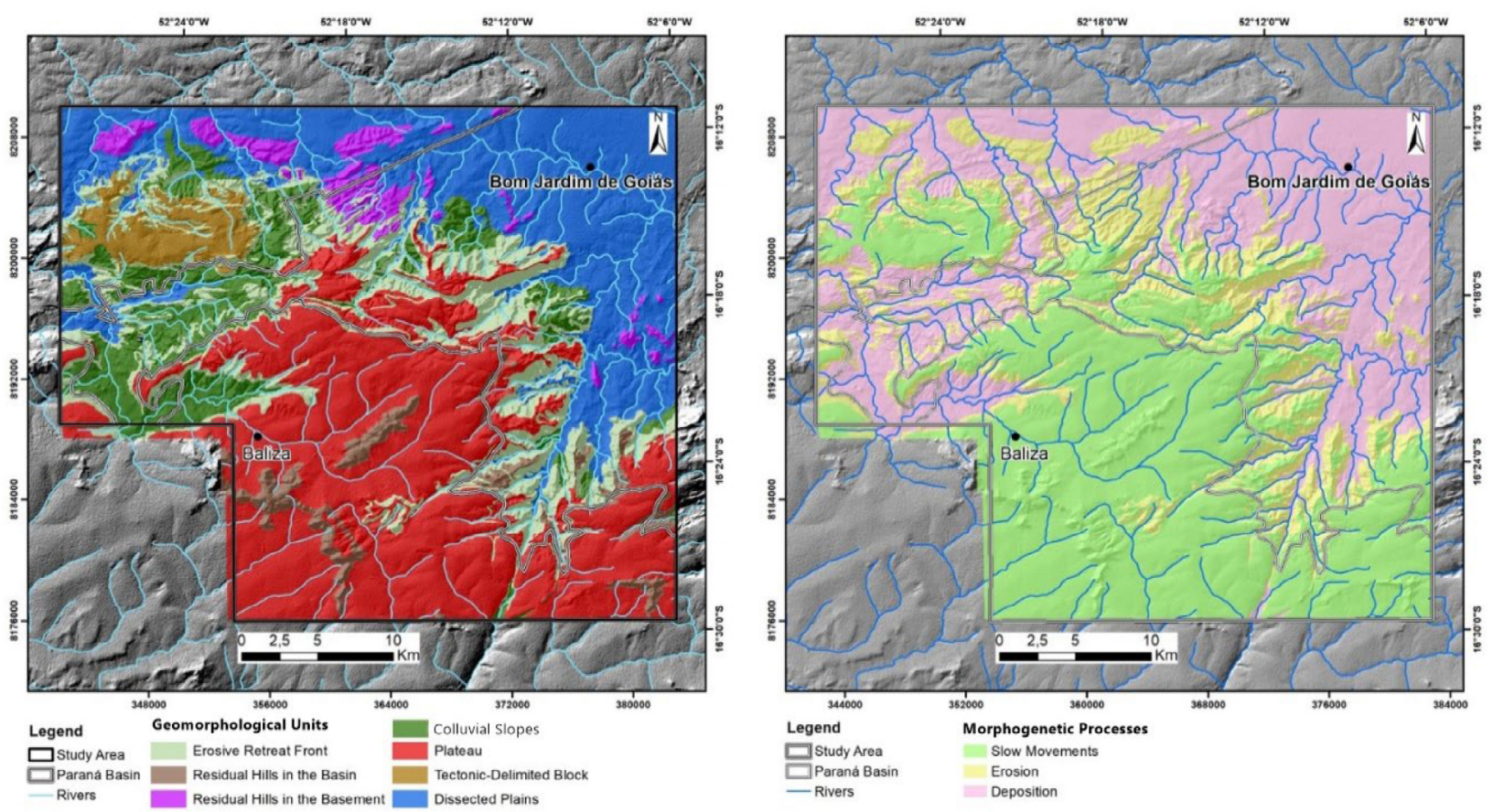

Figure 6. (A) Geomorphological map of the study area showing dissected plains and plateaus as the most expressive units. (B) Morphogenetic processes in the study area.

- Fault-related mesa unit shows high tectonic-structural dynamics, always bordered by drainage, despite being similar to other geomorphological units.

Morphogenetic processes represent the landscape movements responsible for sculpting the relief patterns. The seven units can be grouped into three relief sculpting agents classified as slow movements, deposition, and erosion, which controlled the development of geomorphological units (Fig. 6B). Slow movements sculpted transitional relief areas, erosion sculpted those affected by an intense erosive activity like weather and mass movements, and deposition processes sculpted areas that received residual sediments or were formed by resistant materials such as plateaus or residual hills in the basin.

The basin border/edge indicates a strong relationship between lithological and geomorphological units, e.g., the plains and their scarps form a system in which erosive processes act mostly on the basin boundary. Indeed, different relief types are found within the same geological domain, but geology is not the only factor influencing the landscape. Lineaments, as the record of tectonic events, are especially correlated with $\mathrm{K}_{\mathrm{d}}$ accumulation.

Table 1 summarizes the data from Figure 6. 
Table 1. Geomorphological units classified by morphogenetic processes and their areas.

\begin{tabular}{|c|c|c|}
\hline $\begin{array}{l}\text { Morphogenetic } \\
\text { Processes }\end{array}$ & Geomorphological Units & Area \\
\hline $\begin{array}{l}\text { Slow } \\
\text { Movements }\end{array}$ & $\begin{array}{l}\text { Colluvial Slopes } \\
\text { Dissected Plains }\end{array}$ & $457.47 \mathrm{~km}^{2}$ \\
\hline Erosion & $\begin{array}{c}\text { Scarp Retreat } \\
\text { Residual Hills in the Basement }\end{array}$ & $256.59 \mathrm{~km}^{2}$ \\
\hline Deposition & $\begin{array}{c}\text { Plateau } \\
\text { Fault-related Mesa } \\
\text { Residual Hills in the Basin }\end{array}$ & $538.76 \mathrm{~km}^{2}$ \\
\hline
\end{tabular}

\section{Anomalous potassium trend analysis}

Lineaments were interpreted from the shaded relief image. Only negative breaks were demarcated to identify better the structures while different azimuth directions highlighted the data. Directions perpendicular to N40-70E marked lines in the NE direction, which showed the main reactivations in the area. Lighting at $45^{\circ}$, perpendicular to N40-60W (N40-60E), showed lines associated with events after the TBL. Our lineament analysis results are supported by a previous finding of Seer (1985). Finally, azimuths perpendicular to the TBL (N25E) helped identify the oldest features (Fig. 7):

The rosette diagram shows that lineaments often follow the NE-SW trend, which is the predominant trend observed in the TBL and during the Brazilian Orogeny. At the same time, NW-SE trending lineaments are widely distributed in the area and also important. From this point, $\mathrm{K}_{\mathrm{d}}$ was integrated into lineament buffers, considering a $125 \mathrm{~m}$ margin (size of a pixel).

$\mathrm{K}_{\mathrm{d}}$ was calculated for the different lithological and morphogenetic units (Fig. 8). The basin border and basement environments are lithologically complex and heterogeneous, showing very different radiometric backgrounds. Each unit has distinct $\mathrm{K}_{\mathrm{d}}$ values since rocks with high $\mathrm{K}$ and low $\mathrm{K}$ background concentrations do not contain the same anomalous range of $K_{d}$ values. Figure $8 A$ shows the $K_{d}$ classes of each geological unit, allowing us to analyze other possible factors that influenced the $\mathrm{K}_{\mathrm{d}}$ concentration, beyond the primary mineral contribution. Likewise, $\mathrm{K}_{\mathrm{d}}$ was classified according to the three basic morphogenetic processes (erosion, deposition, and slow movements) to assist in understanding the $\mathrm{K}$ mobilization dynamics. The structural control of morphological processes ends up crossing both pieces of information while examining different parameters.

To simplify the $\mathrm{K}_{\mathrm{d}}$ data analyses, the results were regrouped into three qualitative classes, low, medium, and high $\mathrm{K}_{\mathrm{d}}$ values (Fig. 8). In both maps, most of the medium to high $\mathrm{K}$ values are located along basement lineaments, many near the basin boundary and along the Serra Negra Fault, sites with known erosion and reactivation processes.

\section{Index Overlay Method}

Geological and morphogenetic process data were integrated using the IOM, a flexible technique able to indicate priorities in spatial units under the same influence. Greater weight was assigned to morphogenetic process data, whereas terrain was strongly correlated with structural control and $\mathrm{K}_{\mathrm{d}}$ anomalies, especially for local processes. Furthermore, a morphogenetic process unit can include several lithological units. A new map was produced by intersecting the IOM resulting image and lineament buffers (Fig. 9).

The very high class corresponds to the highest potassium enrichment due to the structures. Positive anomalies are located mostly along N60E, N45E, and between N30W and N45W structures.

\section{Fuzzy logic approach}

Fuzzy logic requires rescaling data since anomalous values are different for each geological or morphogenetic unit. Afterward, $\mathrm{K}_{\mathrm{d}}$ fuzzy membership images were intersected by $125 \mathrm{~m}$ lineament buffers, using the MS Large function in both products (Fig. 10).

As expected, the fuzzy logic final product is more restrictive than the IOM result. Despite the lower number of results, fuzzy logic probably shows the most important lineaments with positive anomalies in the area. Nonetheless, the ambiguity related to the origin of $\mathrm{K}$ accumulations was solved by using the F-Parameter to indicate areas dominated by either weathering or hydrothermal processes.

\section{F-Parameter analysis}

According to Gnojek and Prichystal (1985), low F-Parameter values indicate slightly altered rocks, whereas high values (more than 2) suggest a high concentration of potassium and uranium compared to thorium. Hydrothermalism is expected in such areas (Fig. 11A). In contrast, very low values (less than 1.2 and 1.4), as observed in the Paraná Basin (Fig. 11B), allow assuming that physical weathering and erosive processes are preeminent since these rocks are less chemically altered than others in their surroundings.

\section{DISCUSSION}

Technically, both IOM and fuzzy logic were efficient and could be used as complementary techniques. The first method requires fewer processing steps since weights do not need to be assigned in a predetermined way. On the other hand, the second method allows several types of observations, enabling a restrictive analysis. Furthermore, as it uses integrated geological data as a simple validation, fuzzy logic presented more accurate results compared to IOM.

At the regional scale, the N25-30E direction is the most important TBL expression, being less expressed in the study area for its inherited crustal tectonic features.

We were able to correlate these lineaments to the structural framework generated by tectonic reactivations of the Aldeia and Serra Negra faults in the N-S and N60E directions, respectively. This structural set shows $\mathrm{K}$, eTh, and eU enrichment, mostly related to geological units of the Cuiabá Group and post-tectonic granite intrusions.

Fuzzy logic integration results have considered gamma-ray spectrometric responses associated with geological and structural 


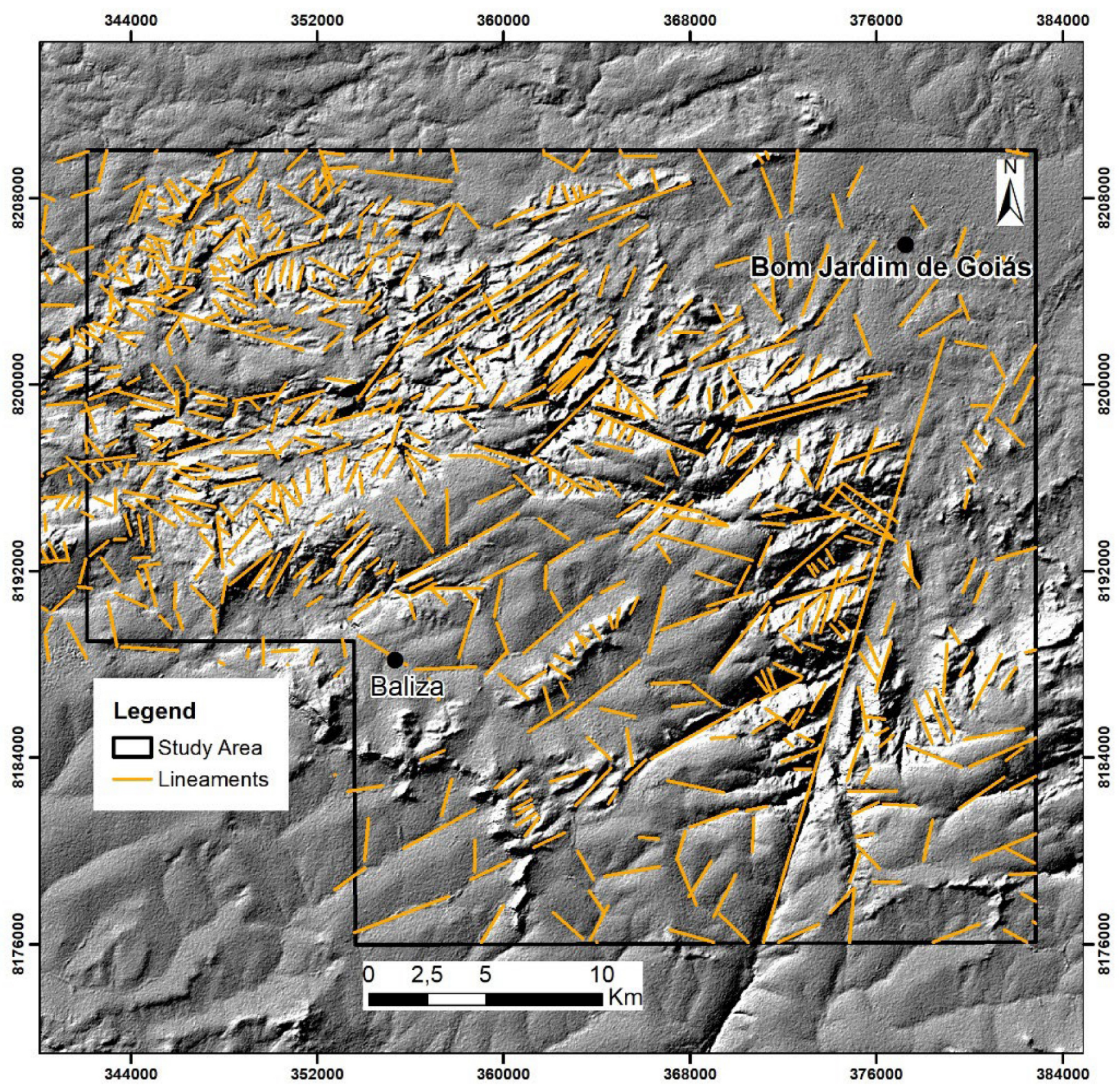

Figure 7. Yellow dashes show the 698 extracted lineaments, obtained by shaded relief data from the ALOS PALSAR sensor. The rosette diagram shows lineament directional trends.

data, highlighting potential areas under the influence of tectonism in landscape configuration and isotopic remobilization by lineaments. High $\mathrm{K}_{\mathrm{d}}$ values related to high F-Parameter values determined for structural features allowed associating these data with those of previous studies by Seer (1985), evidencing tectonic reactivations in the study area and their connection with current relief settings. Hydrothermal activity distribution in the fault scarp relief suggests that footwall topography is an essential parameter for allowing recharge and hydrothermal fluid circulation path (Taillefer et al. 2017).

Locally, relief aspects have a more direct relationship with $\mathrm{K}_{\mathrm{d}}$ accumulation than pure lithology. Different morphogenetic processes are observed (the reverse is not always true) in the same lithological domain, as relief also results from morphostructural and tectonic control.

Geological and morphogenetic processes bind these tectonic dynamics since stable areas correspond to basin units where the environment is quite enduring. Similarly, deposition areas correspond to basement units where tectonics have operated energetically before basin formation and during reactivation in later periods.

Erosion units correspond to transitional activities, with intense erosive activity in slow movement units and material relocation in deposition unit areas.

In the primary tectonic analysis, morphogenesis also included events that formed the Goiás Magmatic Arc and the TBL, establishing the current basement configuration of the morphogenetic deposition unit basin. Occurrences following the basin formation are related to possible reactivations of old basement structures, subsidence in old lineament gutters, and reactivations of shear zones that eventually "tear" the edge of the Paraná Basin, as seen in Seer (1985).

Gamma-ray spectrometry is an excellent hydrothermalism indicator through F-Parameter analysis, which can reflect the abundance ratios of $\mathrm{K}$ and $\mathrm{Th} / \mathrm{U}$ or $\mathrm{U}$ and $\mathrm{Th} / \mathrm{K}$. The integrated $\mathrm{K}_{\mathrm{d}}$ data and F-Parameter extracted from the lineaments 

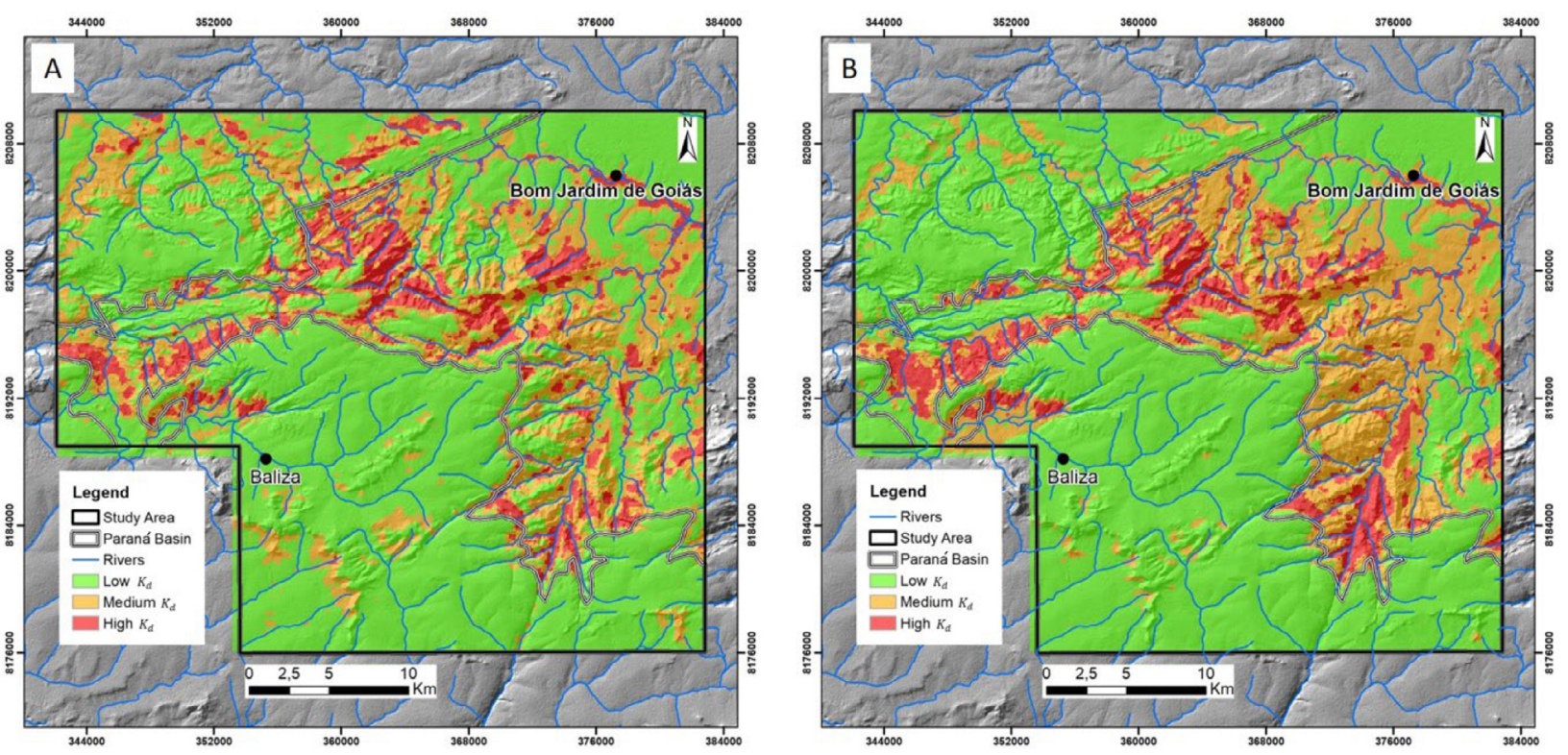

Figure 8. (A) $K_{d}$ obtained from geological data; (B) $K_{d}$ obtained from morphogenetic process data.

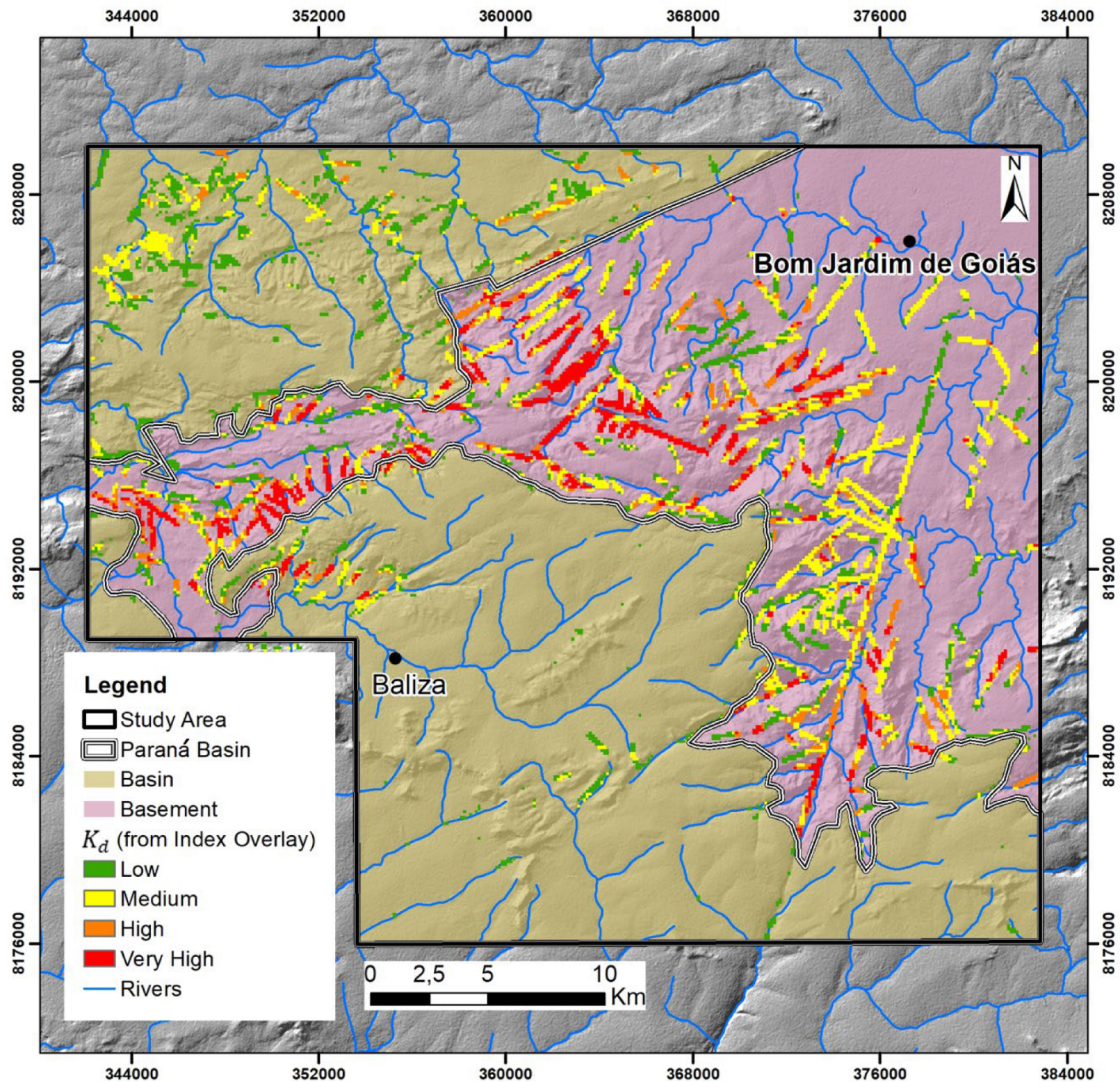

Figure 9. Index Overlay Integration showing the distribution of $\mathrm{K}_{\mathrm{d}}$ classes after extracting the lineaments. 


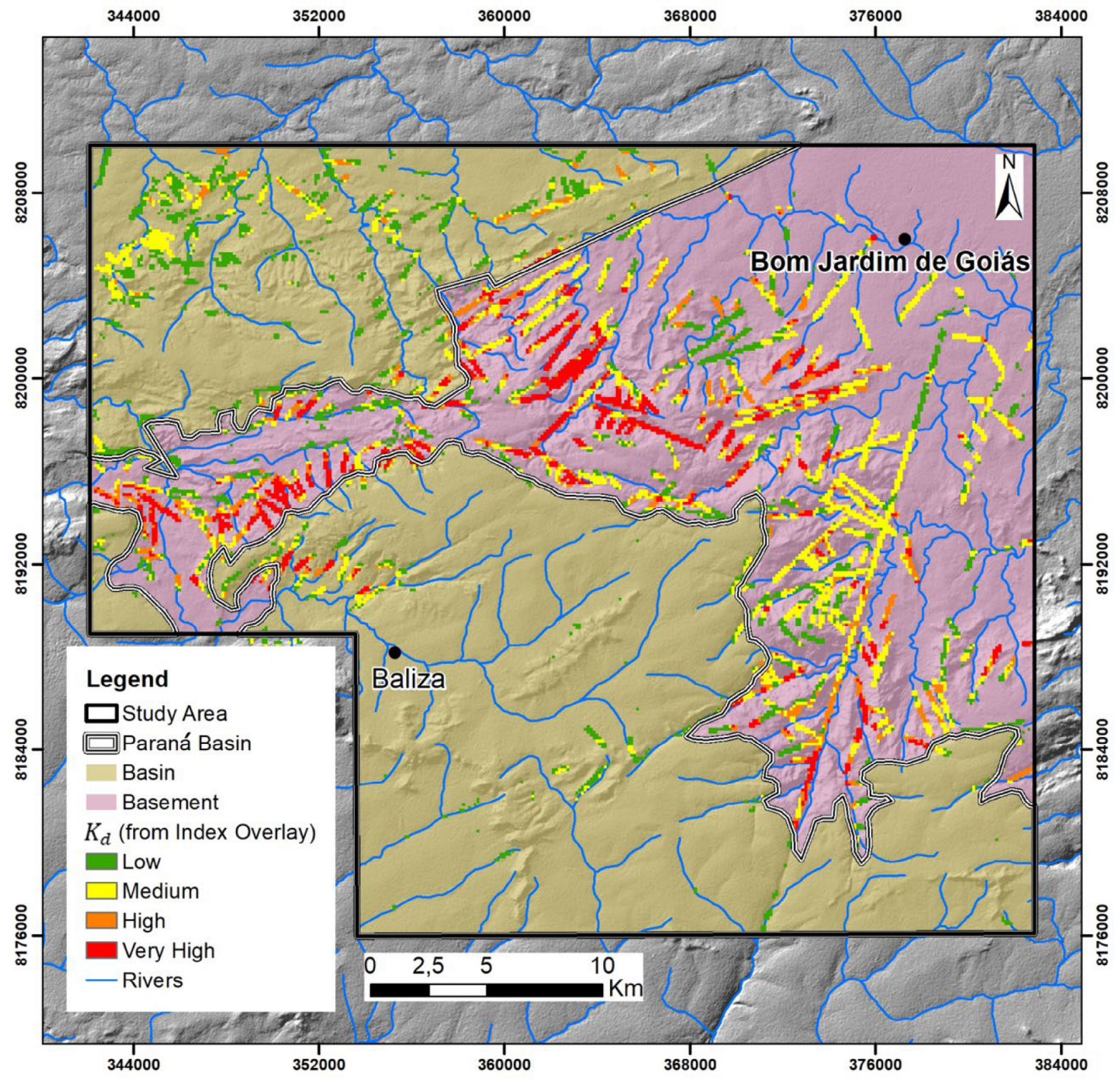

Figure 10. $K_{d}$ values in the area show that most relief lineaments are concentrated in sedimentary basement units (Tocantins Structural Province).
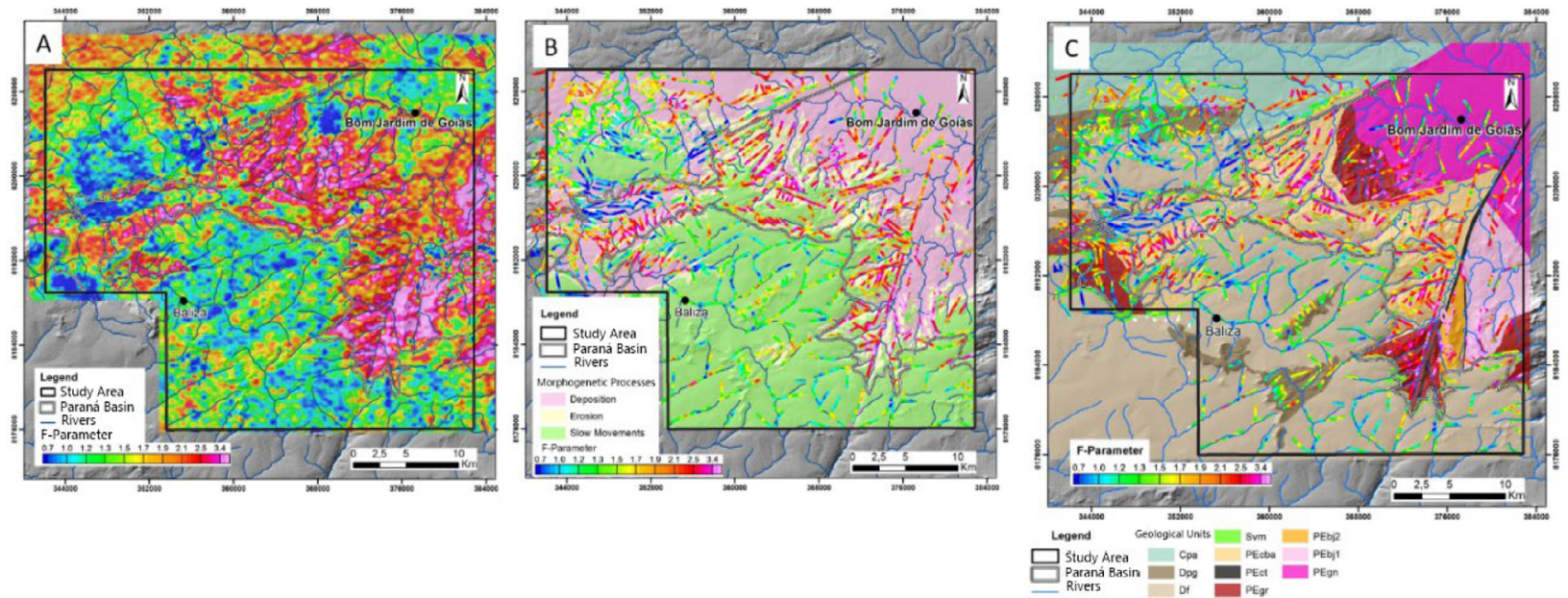

Figure 11. (A) F-Parameter; (B) F-Parameter compared to background morphogenetic processes; (C) F-Parameter compared to background geological units. 
evidenced the hydrothermalism associated with possible tectonic reactivations, highlighted by the combined high $\mathrm{K}_{\mathrm{d}}$ values and F-Parameter. This result is corroborated by Eleraki et al. (2017), who correlated increased Th and K concentrations with tectonic reactivation processes.

Field data and isotope analysis of the lineaments show high concentrations of $\mathrm{K}$, Th, and $\mathrm{U}$, especially in basement areas. In this context, chemical availability is more diverse due to rock composition. Additionally, field data indicated clay mineral formations and quartz intrusions with associated tourmaline of hydrothermal origin, corroborating the F-Parameter analysis.

The direct relationship between morphogenesis and gamma-ray spectrometry is demonstrated by the dynamics and surface analysis of channels, derived from a shallow method. Morphogenetic processes are often responsible for the isotopic mobilization of elements and their concentration in structural features, thus allowing analyzing the origin of each radio element and inter-relationships. In the study area, this fact is evidenced by the K concentration in depositional units, especially in areas of lineament concentrations: the channels served as channels for $\mathrm{K}$ concentration, probably from the reactivation or subsidence of these structures. Since K concentrations are predominantly located in Cuiabá Group domains, the percolation of K-rich fluids in a sedimentary unit supports the reactivation hypothesis.

Also, anomalous values indicate hydrothermalism is concentrated in the basement, with few lineaments belonging to the basin. The highest hydrothermal activity is found in rocks of the Cuiabá and Bom Jardim groups and granitic intrusions of the region. The distribution pattern of the lineaments does not favor any particular lithology, indicating homogeneous hydrothermal activity throughout the basement, a product of reactivations, as seen in Seer (1985).

Moreover, Barbuena et al. (2013) noted that, according to $K_{d}$ data, well-defined lineaments with anomalous values indicate K-rich hydrothermal alteration aligned along faults and lineaments. Similarly, Th and U accumulations are also often related to post-magmatic evidence and hydrothermal processes associated with metamorphism and geomorphological processes (Ulbrich et al. 2009, Ribeiro et al. 2013). The abundance of $\mathrm{K}$ and the $\mathrm{eU} / \mathrm{eTh}$ ratio depend on geomorphological circumstances that favor certain geochemical behavior of elements. These hydrothermal processes can be easily identified (Ostrovskiy 1975, Portnov 1987) by establishing relationships between the F-Parameter, (Efimov 1978 apud Gnojek and Prichystal 1985) and $\mathrm{K}_{\mathrm{d}}$ (Saunders et al. 1994). Figures $12 \mathrm{~A}$ and $12 \mathrm{~B}$ show that most lineaments with high values of fuzzy membership of $\mathrm{K}_{\mathrm{d}}$ integration also present high F-Parameter.

The results indicate that data produced from the integrated analysis of different datasets generated from various processes allow a more cohesive interpretation of established correlations. Pereira and Ferreira (2018) also discussed the correlation between the $\mathrm{K}_{\mathrm{d}}$ and F-Parameter and identified areas favorable to hydrothermal mineralization. The analysis confirmed high favorability in areas where the $\mathrm{K}_{\mathrm{d}}$ and F-Parameter correlation is high.

Furthermore, drag folds, clay-filled fractures, normal faults, and breccia with obliterated quartz and kaolin, as well as the displacement of the Furnas Formation in relation to the Cuiabá Group due to normal faulting, were indicators of fault reactivation (Assumpção and Sacek 2013) found in the field (Fig. 1, point 0BJ-14B).

Tectonics, temporal agents, and fluid surface dynamics govern the landscape evolution by directly affecting the isotopic composition measured in the gamma-ray spectrometry data. The tectonic processes forming the described structures also play a role in the chemical composition of the circulating fluids, through hydrothermal alterations and the weathering

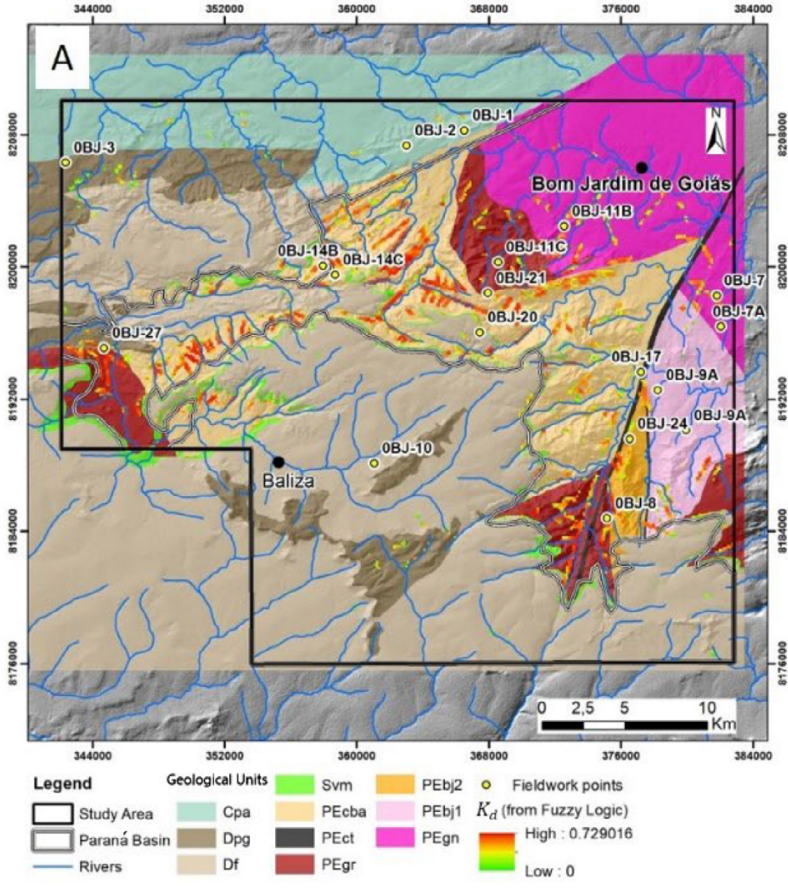

Figure 12. (A) Fieldwork points with fuzzy membership lineaments.

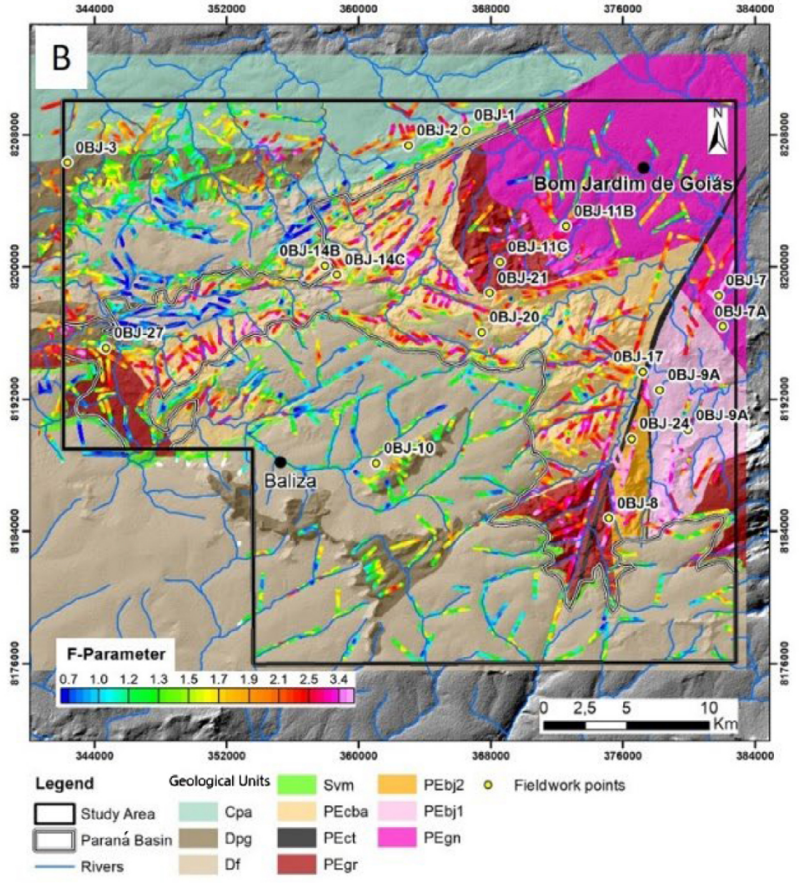

(B) Fieldwork points with F-Parameter lineaments. 
generated by erosive morphogenetic relief processes (Pinheiro et al. 2019).

The changing surface dynamics also reflects the formation of lateritic crusts in the study area. X-ray analyses show that lateritic crusts in the Aquidauana Formation contain illite, a secondary mineral originated from the weathering of muscovite-rich material. These processes also remobilize $\mathrm{K}$, which may result in anomalous concentration. Sandstones of the Vila Maria Formation also present surface accumulation of muscovite.

\section{Conclusions}

The characterized geomorphometric features allow a deeper understanding of tectonic events while elucidating the consequences on surface dynamics and landscape shaping during the geological evolution of the northern Paraná Basin from the Paleozoic-Mesozoic to the Pleistocene. The correlation between anomalous targets and the dynamic context of landscape modeling indicates how tectonics may have promoted the remobilization of chemical elements. This work demonstrates that many lineaments are located in erosive units, confirming that tectonic reactivation processes can enhance the anomalous concentration of potassium. Although the predominant
NE-SW trend of the Serra Negra Fault is broadly observed, NW-SE lineaments are also noticed, suggesting that structures can act together in terrain dynamics and obliterated sediment deposits. The multidisciplinary approach adopted has successfully proven the role of tectonic reactivations in the study area, thus representing a useful tool that can be applied to other regions with similarly enigmatic geotectonic settings.

\section{ACKNOWLEDGMENTS}

We thank the reviewers of the Brazilian Journal of Geology for their enriching contribution and shared experience. Thanks are also due to the Universidade de Brasília (UNB) and the Coordination for the Improvement of Higher Education Personnel (Coordenação de Aperfeiçoamento de Pessoal de Nível Superior - CAPES) for the financial support to the project. This study was partly funded by CAPES Brasil - Finance Code 1790503. We would also like to thank the Geological Survey of Brazil (Serviço Geológico do Brasil - CPRM) for providing geophysical data for academic purposes, Geosoft for providing the software Oasis Montaj 8.1, and the Applied Geoscience Program for allowing us to use their facilities.

\section{ARTICLE INFORMATION}

Manuscript ID: 20190018. Received on: 12/07/2019. Approved on: 08/11/2020.

A.R. wrote the first draft of the manuscript, improved the final version of the text, and prepared Figures 1 to 12. J.C. acted as advisor in the sections Geological Setting, Database \& Processing, and Results, in addition to guiding the main topics on Discussion and Conclusions. J.C. also revised and improved the manuscript with corrections and suggestions. H.S. acted as advisor in the Discussion and Conclusions sections regarding structural geology, as well as improved the manuscript with corrections and suggestions. H.S. also revised the manuscript. Competing interests: The authors declare no competing interests.

\section{REFERENCES}

Alamaniots M., Heifetz A., Raptis A.C., Tsoukalas L.H. 2013. FuzzyLogic Radioisotope Identifier for Gamma Spectroscopy in Source Search. IEEE Transactions on Nuclear Science, 60(4):3014-3024. https://doi. org/10.1109/TNS.2013.2265307

Almeida F.F.M. 1967. Origem e evolução da Plataforma Brasileira. Rio de Janeiro: Departamento Nacional da Produção Mineral, Divisão de Geologia e Mineralogia, $36 \mathrm{p}$.

Alvarenga C.J.S., Figueiredo M.F., Babinski M., Pinho F.E.C. 2007. Glacial diamictites of Serra Azul Formation (Ediacaran, Paraguay Belt): evidence of the Gaskiers glacial event in Brazil. Journal of South American Earth Science, 23(2-3):236-241. https://doi.org/10.1016/j.jsames.2006.09.015

Alvarenga C.J.S., Trompette R. 1993. Evolução tectônica Brasiliana da Faixa Paraguai: a estruturação da Região de Cuiabá. Revista Brasileira de Geociências, 23(1):18-30.

Andrade A.P.U., Alvarenga C.J.S., Fuck R.A. 2012. Influência do Lineamento Transbrasiliano na borda norte da Bacia do Paraná, divisa Mato Grosso Goiás. In: Congresso de Geologia, 46., 2012. Annals... SBG.

Assine M.L. 2004. A bacia sedimentar do Pantanal Mato-Grossense. In: Mantesso Neto V., Bartorelli A., Carneiro C.D.R., Brito Neves B.B. (eds.). Geologia do continente sul-americano: evolução da obra de Fernando Flávio Marques de Almeida. São Paulo: Beca, p. 61-74.

Assumpção M., Sacek V. 2013. Intra-plate seismicity and flexural stresses in Central Brazil. Geophysical Research Letters, 40(3):487-491. https://doi. org/10.1002/grl.50142

Barbuena D., Souza Filho C.R., Leite E.P., Miguel Junior E., Assis R.R., Xavier R.P., Ferreira F.J.F., Barros A.J.P. 2013. Airborne Geophysical Data
Analysis Applied To Geological Interpretation In The Alta Floresta Gold Province, Mt. Brazilian Journal of Geophysics, 31(1):169-86. http://dx.doi. org/10.22564/rbgf.v31i1.254

Batezelli A., Saad A.R.,Perinotto J.A. de J., Fulfaro V.J.2006. Análise Estratigráfica Aplicada à Reconstrução Paleogeográfica da Porção Norte e Nordeste da Bacia Bauru (Cretáceo Superior). Revista Brasileira de Geologia, 36(2):253-268.

Bonham-Carter G.F. 1994. Geographic Information Systems for Geoscientists: Modelling with GIS (Computer Methods in the Geosciences 13). New York: Pergamon Press.

Brito Neves B.B., Fuck R.A. 2013. Neoproterozoic evolution of the basement of the South-American plataform. Jornal of South American Earth Sciences, 47:72-89. https://doi.org/10.1016/j.jsames.2013.04.005

Castro K.B., Martins E.S., Gomes M.P., Reatto A., Lopes C.A., Passo D.P. Lima L.A.S., Cardoso W.S., Carvalho Junior O.A., Gomes R.A.T. 2010. Caracterização geomorfológica do município de Luís Eduardo Magalhães, Oeste Baiano, escala 1:100.000. Planaltina: Embrapa Cerrados, 33 p. v. 288.

Cianfarra P., Salvini F. 2014. Ice sheet surface lineaments as nonconventional indicators of East Antarctica bedrock tectonics. Geosphere, 10(6):1411-1418. https://doi.org/10.1130/GES01074.1

Cordani U.G., Brito Neves B.B., D’Agrella Filho M.S. 2003. From Rodinia to Gondwana: a review of the available evidence from South America. Gondwana Research, 6(2):275-283. https://doi.org/10.1016/S1342-937X(05)70976-X

Cordani U.G., Brito Neves B.B., Thomaz Filho A. 2010. Estudo preliminar de integração do Pré- Cambriano com os eventos tectônicos das bacias sedimentares brasileiras (Atualização). Boletim de Geociências da Petrobras, 17:205-219. 
Curto J.B. 2015. O lineamento transbrasiliano na Bacia do Paraná: compartimentação crustal do embasamento e reativações fanerozóicas. Thesis, Universidade de Brasília, Brasília, 184 p.

Curto J.B., Vidotti R.M., Fuck R.A., Blakely R.J., Alvarenga C.J.S., Dantas E.L. 2014. The tectonic evolution of the Transbrasiliano Lineament in northern Paraná Basin, Brazil, as inferred from aeromagnetic data. Journal of Geophysical Research: Solid Earth, 119(3):1544-1562. https://doi. org/10.1002/2013JB010593

Efimov A.V. 1978. Multiplikativniyi pokazatel dlja vydelenija endogennych rud aerogamma-spectrometriceskim dannym. Metody rudnoj geofiziki. Leningrado: Naucno-Proizvodstvennoje Objedinenie Geofizica.

Eleraki M., Ghieth B., El-Rahman N., Zamzam S. 2017. Hydrothermal Zones Detection Using Airborne Magnetic and Gamma Ray Spectrometric Data of Mafic/Ultramafic Rocks at Gabal El-Rubshi Area, Central Eastern Desert (CED), Egypt. Advances in Natural and Applied Sciences, 11(9):182-196.

ESRI. 2019. FAQ: What is the Jenks optimization method. Available at: <https://support.esri.com/en/technical-article/000006743>. Accessed on: June 27, 2019.

Gnojek I., Prichystal A. 1985. A new zinc mineralization detected by airborne gamma-rayspectrometryinnorthernMoravia(Czechoslovakia).Geoexploration, 23(4):491-502. https://doi.org/10.1016/0016-7142(85)90076-6

Harcouet-Menou V., Guillou-Frottier L., Bonneville A., Adler P., Mourzenko V. 2009. Hydrothermal convection in and around mineralized fault zones: Insights from two- and three-dimensional numerical modeling applied to the Ashanti belt, Ghana. Geofluids, 9(2):116-137. https://doi. org/10.1111/j.1468-8123.2009.00247.x

Hermuche P.M., Guimarães R.F., Carvalho A.P.F., Martins E.S., Fukss D., Carvalho Junior O.A., Santos N.B.F., Reatto A. 2002. Morfometria como Suporte para Elaboração de Mapas Pedológicos: I. Bacias Hidrográficas Assimétricas. Planaltina: Embrapa Cerrados, 25 p. v. 68.

Instituto Brasileiro de Geografia e Estatística (IBGE). 2009. Manual Técnico em Geomorfologia, 5. Brasil: IBGE.

International Atomic Energy Agency (IAEA). 2002. Specialized software utilities for gamma ray spectrometry: Final report of a co-ordinated research project 1996-2000. Vienna: Physics Section, International Atomic Energy Agency Wagramer Strasse 5.

International Atomic Energy Agency (IAEA). 2003. Guidelines for radioelement mapping using gamma ray spectrometry data. Vienna: International Atomic Energy Agency.

Lucianetti G., Cianfarra P., Mazza R. 2017. Lineament domain analysis to infer groundwater flow paths: Clues from the Pale di San Martino fractured aquifer, Eastern Italian Alps. Geosphere, 13(5):1729-1746. https://doi. org/10.1130/GES01500.1

Machado C.C., Souza A.P. 1990. Impacto ambiental das estradas florestais: causas e controle. Viçosa: SIF.

Macrozoneamento Agroecológico e Econômico do Estado de Goiás (MacroZEE). 2014. Produto I, III, V. Available at: <http://www.zee.go.gov. br/macro-zaee/>. Accessed on: June 27, 2019.

Marini J.O., Fuck R.A., Danni J.M.C., Dardenne M.A., Loguercio S.O.C., Ramalho R. 1984. As Faixas de Dobramentos Brasília, Uruaçu e Paraguai-Araguaia e o Maciço Mediano de Goiás. In: Schobbenhaus C. (ed.). Geologia do Brasil: Texto explicativo do mapa geológico do Brasil e da área oceânica adjacente incluindo depósitos minerais. Escala 1:2.500.000. Brasil: MME-DNPM, p. 251-303.

Marques A., Zanotto O.A., França A.B., Astolfi M.A.M., Paula O.B. 1993. Compartimentação tectônica da Bacia do Paraná. Relatório Interno. Brasil: Petrobras/NEXPAR, $87 \mathrm{p}$.

Milani E.J., Melo J.H.G., Souza P.A., Fernandes L.A., França A.B. 2007. Bacia do Paraná. Boletim de Geociências da Petrobras, 15, 265-287.

Moura A.C.A. 2017. Datação $40 \mathrm{Ar} / 39$ Ar em zonas de cisalhamento ao longo do Lineamento Transbrasiliano: evolução e reativação. Thesis, Universidade de Brasília, Brasília, 119 p.

Oliveira D.C. 2001. Reavaliação da evolução tectonomagmática do Graben de Jaibaras (Nordeste do Brasil). Acta Geologica Hispanica, 36(1-2):53-95.

Ostrovskiy E.Y. 1975. Antagonism of radioative elements in wallrock alterations fields and its use in aerogamma spectrometric prospecting. International Geology Review, 17(4):461-468. https://doi. org/10.1080/00206817509471687

Pereira B.M., Ferreira F.J.F. 2018. Recognition of gold mineralization favorability zones through airborne gamma-ray spectrometry and magnetometry in brusque and Botuverá region, southern Brazil. Brazilian Journal of Geophysics, 36(3):361-374. http://dx.doi.org/10.22564/rbgf. v36i3.1953

Pike R.J., Evans I.S., Heng T. 2009. Geomorphometry: A Brief Guide. Developments in Soil Science, 33:3-30. https://doi.org/10.1016/ S0166-2481(08)00001-9

Pimentel M.M. 2016. The tectonic evolution of the Neoproterozoic Brasília Belt, central Brazil: a geochronological and isotopic approach. Brazilian Journal of Geology, 46(Suppl. 1):67-82. https://doi. org/10.1590/2317-4889201620150004

Pimentel M.M., Fuck R.A. 1987. Late Proterozoic granitic magmatism in southwestern Goiás, Brazil. Revista Brasileira de Geociências, 17(4):415-425.

Pimentel M.M., Fuck R.A. 1992a. Características geoquímicas e isotópicas de unidades metavulcânicas e ortognáissicas neoproterozóicas do oeste de Goiás. Boletim da Sociedade Brasileira de Geologia, Núcleo Centro-Oeste, 15:1-22.

Pimentel M.M., Fuck R.A. 1992b. Neoproterozoic crustal accretion in central Brazil. Geology, 20(4):375-379. https://doi. org/10.1130/0091-7613(1992)020\%3C0375:NCAICB\%3E2.3.CO;2

Pimentel M.M., Fuck R.A., Ferreira Filho C.F., Araújo S.M. 2000a. The basement of the Brasilia Belt and the Goiás Magmatic Arc. In: Cordani U.G., Milani E.J., Thomaz Filho A., Campos D.A. (eds.). Tectonic Evolution of South America. Rio de Janeiro: 31st International Geological Congress, p. 195-229.

Pimentel M.M., Fuck R.A., Fischel D.P. 1999. Estudo isotópico SmNd regional da porção central da Faixa Brasília, Goiás: implicações para idade e origem dos granulitos do complexo Anápolis-Itauçu e rochas metassedimentares do Grupo Araxá. Revista Brasileira de Geociências, 29(2):271-276

Pimentel M.M., Fuck R.A., Gioia S.M.C.L. 2000b. The Neoproterozoic Goiás Magmatic Arc, Central Brazil: A review and new Sm-Nd Isotopic Data. Revista Brasileira de Geociências, 30(1):35-39.

Pinheiro M.R., Cianfarra P., Villela F.N.J., Salvini F. 2019. Tectonics of the Northeastern border of the Parana Basin (Southeastern Brazil) revealed by lineament domain analysis. Journal of South American Earth Sciences, 94:102231. https://doi.org/10.1016/j.jsames.2019.102231

Pinto M.L., Vidotti R.M. 2019. Tectonic framework of the Paraná basin unveiled from gravity and magnetic data. Journal of South American Earth Sciences, 90:216-232. https://doi.org/10.1016/j.jsames.2018.12.006

Pires A.C.B. 1995. Identificação geofísica de áreas de alteração hidrotermal, Crixás-Guarinos, Goiás. Revista Brasileira de Geociências, 25(1):61-68.

Pischiutta M., Anselmi M., Cianfarra P., Rovelli A., Salvini F. 2013. Directional site efects in a non-volcanic gas emission area (Mefite d'Ansanto southern Italy): Evidence of a local transfer fault transversal to large NW-SE extensional faults? Physics and Chemistry of the Earth, 63:116-123. https:// doi.org/10.1016/J.pce.2013.03.008

Portnov A.M. 1987. Specialization of rocks toward potassium and thorium in relation to mineralization. International Geology Review, 29(3):326-344. https://doi.org/10.1080/00206818709466149

Ribeiro V.B., Mantovani M.S.M., Louro V.H.A. 2013. Aerogamaespectrometria e suas aplicações no mapeamento geológico. Terra e Didática, 10:29-51.

Saunders D.F., Branch J.F., Thompson C.K. 1994. Tests of Australian aerial radiometric data for use in petroleum reconnaissance. Geophysics, 59(3):411-419. https://doi.org/10.1190/1.1443603

Schobbenhaus C., Gonçalves J. H., Santos J. O. S., Abram M. B., Leão Neto R., Matos G. M. M., Vidotti R. M.. Ramos M. A. B.. Jesus J. D. A. 1975. Texto Explicativo, Folha Goiás SD.22. In: Schobbenhaus C. (ed.). Carta Geológica do Brasil ao Milionésimo. Brasília: DNPM, 99 p.

Seer H.J. 1985. Geologia, deformação e mineralização de cobre no complexo vulcanossedimentar de Bom Jardim de Goias. Dissertation, Universidade de Brasília, Brasília, 181 p. 
Soares P.C., Barcellos P.E., Csordas S.M. 1982. Lineamentos em imagens de landsat e radar e suas implicações no conhecimento tectônico da Bacia do Paraná. In: Simpósio Brasileiro de Sensoriamento Remoto, 1., 1982. Annals..., 143-167.

Sousa E.M. 2017. Arcabouço estrutural da porção sul da Bacia do Bananal e reativações transbrasilianas. Dissertation, Universidade de Brasília, Brasília, 89 p.

Taillefer A., Soliva R., Guillou-Frottier L., Le Goff E., Martin G., Seranne M. 2017. Fault-Related Controls on Upward Hydrothermal Flow: An Integrated Geological Study of the Têt Fault System, Eastern Pyrénées (France). Geofluids, 2017:8190109. https://doi.org/10.1155/2017/8190109

Tokashiki C.C., Saes G.S. 2008. Revisão estratigráfica e faciologia do Grupo Cuiabá no alinhamento Cangas-Poconé, baixada Cuiabana, Mato Grosso. Revista Brasileira de Geociências, 38(4):661-675.

Ulbrich H.H.G.J., Ulbrich M.N.C., Ferreira F.J.F., Alves L.S., Guimarães G.B., Fruchting A. 2009. Levantamentos Gamaespectrométricos em Grani- ectrométricos em Granitos Diferenciados. Revisão da Metodologia e do Comportamento Geoquímico dos Elementos $\mathrm{K}$, Th e U. Geologia USP. Série Cientifica, 9(1):33-53. https://doi.org/10.5327/ Z1519-874X2009000100003

Vidotti R.M., Curto J.B., Fuck R.A., Dantas E.L., Almeida T. 2011. Magnetic expression of the Transbrasiliano Lineament, Brazil. In: American Geophysical Union Fall Meeting, 17., 2011. Abstracts...

Zalán P.V., Wolf S., Conceição J.C.J., Astolfi M.A.M., Vieira I.S., Appi V.T., Zanotto O.A. 1987. Tectônica e Sedimentação da Bacia do Paraná. In: Simpósio Sul-Brasileiro de Geologia, 3., 441-447, Curitiba. Annals...

Zalán P.V., Wolf S., Conceição J.C.J., Astolfi M.A.M., Vieira I.S., Appi V.T., Zanotto O.A., Marques A. 1991. Tectonics and sedimentation of the Paraná Basin. In: Ulbrich H., Rocha Campos A.C. (eds.). Gondwana Seven. Proceedings 1. São Paulo: Instituto de Geociências da USP, p. 83-117. 